STUDIA I PRACE WYDZIAKU NAUK EKONOMICZNYCH I ZARZĄDZANIA NR 39, t. 1

DOI:10.18276/sip.2015.39/1-12

\author{
Anna Turczak* \\ Zachodniopomorska Szkoła Biznesu w Szczecinie \\ Patrycja Zwiech $^{* *}$ \\ Uniwersytet Szczeciński
}

\title{
CZYNNIKI OKREŚLAJĄCE JAKOŚĆ ŻYCIA ZAWODOWEGO W ZALEŻNOŚCI OD WYKSZTAŁCENIA PRACOWNIKA
}

\section{Streszczenie}

Czynnikiem, który jest najczęściej wymieniany jako kluczowy dla oceny jakości własnego życia zawodowego, jest odpowiednia płaca. Kolejnymi cechami, które przesądzają o postrzeganiu danej pracy jako atrakcyjnej, są brak napięć i stresów, stabilność zatrudnienia oraz praca zgodna $z$ umiejętnościami. Celem artykułu jest odpowiedź na pytanie, w jakim stopniu wykształcenie osoby rzutuje na to, które cechy uważane są przez nią za najważniejsze w pracy zawodowej, a którym nadaje najmniejszą rangę. W drodze przeprowadzonych badań wykazano, iż czynnikiem, w przypadku którego wykształcenie respondenta ma największy wpływ na wagę przypisaną czynnikowi, jest możliwość rozwoju osobistego.

Słowa kluczowe: jakość życia zawodowego, poziom wykształcenia

* Adres e-mail: aturczak@zpsb.szczecin.pl.

** Adres e-mail: patrycjazwiech@tlen.pl. 


\section{Wprowadzenie}

Ludzie są najważniejszym zasobem każdej organizacji i stąd niezmiernie istotnym zagadnieniem jest właściwe zarządzanie ich potencjałem ${ }^{1}$. Właściwe zarządzanie kapitałem ludzkim to takie, w którym potrzeb organizacji nie stawia się w opozycji do potrzeb pracowników, ale dąży się do tego, aby cele organizacji wspierały realizację potrzeb pracowników i na odwrót. Wydajność pracy nie jest bowiem jedynie pochodną wyposażenia technicznego, środowiska pracy i jej organizacji, ale w bardzo dużym stopniu zależy od stosunku pracownika do swoich obowiązków i do pracodawcy. Wydajnie pracuje ta osoba, która chce tak pracować, a nie tylko umie i może. Dzięki odczuwaniu satysfakcji praca nie jest postrzegana przez pracownika jako uciążliwy obowiązek, ale jako coś przyjemnego. Bardzo ważne jest więc poznanie przez pracodawcę czynników kształtujących zaangażowanie pracowników w pracę, a w szczególności uświadomienie sobie zróżnicowania źródeł ich motywacji.

Zadowolenie zatrudnionego sprzyja budowaniu jego lojalności wobec pracodawcy. Należy pamiętać, że satysfakcja pracownika wpływa zawsze stymulująco na jego wyniki i ma pozytywne przełożenie na osiąganą jakość ${ }^{2}$. Z kolei konsekwencją braku zadowolenia z pracy jest spadek zainteresowania uzyskiwaną wydajnością i jakością, niechęć, bierność wobec stawianych wymagań, a nawet jawna niesubordynacja.

Rozmaite elementy wpływają na zadowolenie ludzi z pracy ${ }^{3}$. Każdy pracodawca powinien więc być zainteresowany poznaniem znaczenia przypisywanego różnym bodźcom motywacyjnym, które to znaczenie jest różne w zależności od wieku ${ }^{4}$, płci czy poziomu wykształcenia pracownika. Celem niniejszego artykułu jest określenie,

1 M. Gitling, Człowiek i jego praca, „Nierówności Społeczne a Wzrost Gospodarczy” 2013, nr 33, s. 212-213; M. Kunasz, Zasoby przedsiębiorstwa w ujęciu teorii ekonomii, „Gospodarka Narodowa" 2006, nr 10, s. 33.

2 M. Głowacka, A. Głowacka-Rębała, I. Nowakowska, R. Rasińska, Zarządzanie jakościa pracy członków organizacji, „Problemy Zarządzania” 2011, Vol. 9, nr 4 (34), s. 220.

3 A. Zalewska, Wiek, płeć i stanowisko pracy a zadowolenie z pracy, „Psychologia Jakości Życia” 2009, t. 8, nr 1, s. 2.

4 E. Mazur-Wierzbicka, Kompetencje pokolenia $Y$-wybrane aspekty, „Studia i Prace Wydziału Nauk Ekonomicznych i Zarządzania” 2015, t. 3, nr 39, s. 307-320. 
w jakim stopniu poziom wykształcenia pracownika rzutuje na to, które czynniki są dla niego najważniejsze w określaniu atrakcyjności pracy zawodowej.

\section{Czynniki określające jakość życia zawodowego}

We współczesnym świecie praca zawodowa pochłania znaczną część czasu dorosłego człowieka ${ }^{5}$. Jakość pracy zawodowej w istotnym stopniu decyduje o ogólnej jakości życia, a wykonywany zawód jest główną determinantą statusu społecznego i poziomu konsumpcji ${ }^{6}$.

Praca zawodowa określa pozycję jednostki oraz jej gospodarstwa domowego w społeczeństwie ${ }^{7}$. Z rodzajem wykonywanej pracy wiąże się określony prestiż i model życia. Zawód dla wielu ludzi stał się głównym miernikiem ich wartości i podstawą oceny innych w codziennych kontaktach zawodowych i pozazawodowych ${ }^{8}$. Praca nie jest jedynie źródłem dochodu, lecz pozwala także spełniać wiele innych oczekiwań człowieka ${ }^{9}$, daje pracownikowi możliwość zaspokojenia nie tylko jego potrzeb materialnych, ale również pozamaterialnych, takich jak samorealizacja, poczucie akceptacji, przynależności do grupy itp.

W latach 2007, 2009 i 2011 GUS przeprowadził badanie ${ }^{10}$ dotyczące wpływu pracy na jakość życia Polaków. W ramach tych badań poproszono respondentów o wskazanie czynników, które uważają za najważniejsze w swojej pracy zawodowej. Respondenci najczęściej wymieniali odpowiednią płacę jako ten czynnik, który przesądza o postrzeganiu danej pracy jako atrakcyjnej. W następnej kolejności osoby ankietowane podawały brak napięć i stresów, stabilność zatrudnienia, pracę zgodną

5 M. Wyrostek, Praca jako determinanta jakości życia człowieka, Prace i Materiały Wydziału Zarządzania Uniwersytetu Gdańskiego” 2013, „Zarządzanie i Finanse” nr 1, cz. 3, s. 499.

6 W. Drzeżdżon, Wartości pracy wśród młodzieży szkół zawodowych, Bernardinum, Tczew 2006, s. 73-78.

7 L. Kozioł, Motywacja w pracy. Determinanty ekonomiczno-organizacyjne, Wydawnictwo Naukowe PWN, Warszawa-Kraków 2002, s. 27.

8 K. Polek-Duraj, Humanizacja pracy w aspekcie jakości pracy $i$ życia społeczeństwa, „Studia i Materiały Miscellanea Oeconomicae" 2010, nr 2, s. 240.

9 W. Drzeżdżon, Przeobrażenia polskiego rynku pracy u progu XXI wieku. Wyzwania dla pedagogiki pracy, „Studia Gdańskie. Wizje i Rzeczywistość” 2011, t. 8, s. 242.

10 Kapital ludzki w Polsce w 2010 r., GUS, Gdańsk 2012; Kapital ludzki w Polsce w 2012 r., GUS, Gdańsk 2014. 
z umiejętnościami, dużą samodzielność, możliwość rozwoju osobistego, dogodne godziny pracy, możliwość szybkiego awansowania, zajęcie poważane przez ludzi, długi urlop oraz możliwość wykonywania pracy w domu. Na rysunku 1 zobrazowano częstość występowania poszczególnych odpowiedzi w 2007, 2009 i 2011 r.

Rysunek 1. Czynniki wymieniane jako najważniejsze w pracy zawodowej

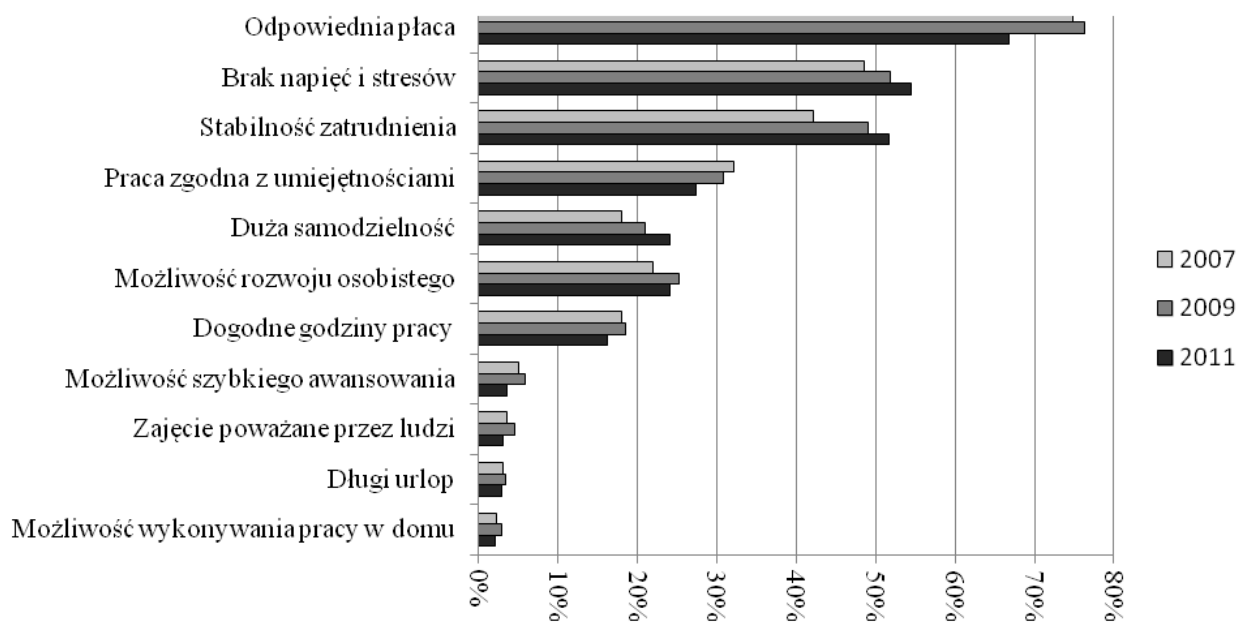

Źródło: opracowanie własne na podstawie: Kapital ludzki w Polsce w 2010 r., GUS, Gdańsk 2012, s. 344; Kapital ludzki w Polsce w 2012 r., GUS, Gdańsk 2014, s. 254.

Dla osób posiadających różne poziomy wykształcenia odmienne jest znaczenie poszczególnych czynników rozważanych przy ocenie jakości własnego życia zawodowego. Warto byłoby więc odpowiedzieć na pytanie, w jakim stopniu wykształcenie respondenta rzutuje na to, które czynniki uważane są przez niego za najważniejsze w pracy zawodowej, a którym przypisuje najmniejszą wagę. W celu udzielenia odpowiedzi na tak postawione pytanie sformułowano jedenaście odrębnych hipotez badawczych. Hipotezy te stanowią, iż istnieje statystycznie istotny związek między wykształceniem respondenta a tym, czy przy ocenie atrakcyjności pracy ważna jest dla niego (1) odpowiednia płaca, (2) brak napięć i stresów, (3) stabilność zatrudnienia, (4) praca zgodna z umiejętnościami, (5) duża samodzielność, (6) możliwość rozwoju osobistego, (7) dogodne godziny pracy, (8) możliwość szybkiego awansowania, (9) zajęcie poważane przez ludzi, (10) długi urlop, (11) możliwość wykonywania 
pracy w domu. Do weryfikacji postawionych hipotez posłużył test niezależności chi-kwadrat ${ }^{11}$. Określona została również siła i charakter zależności między wykształceniem a każdym z jedenastu czynników wskazywanych przy ocenie pracy zawodowej. Do określenia siły występujących zależności użyty został współczynnik $V$ Cramera $^{12}$. Obliczenia przeprowadzone zostały osobno dla 2007, 2009 i $2011 \mathrm{r}$.

\section{Wpływ poziomu wykształcenia pracownika na czynniki określające atrakcyjność pracy}

Aby otrzymać odpowiedź na pytanie, czy istnieje statystycznie istotna zależność między tym, jakie jest wykształcenie danej osoby, a tym, jakie znaczenie mają dla niej poszczególne czynniki opisujące atrakcyjność pracy, zweryfikowano 11 hipotez. Weryfikacji podlegała hipoteza $H_{0}$ stanowiąca, że badane dwie cechy są stochastycznie niezależne, wobec hipotezy alternatywnej $H_{1}$ orzekającej, że występuje stochastyczna zależność między tymi cechami ${ }^{13}$. Procedurę weryfikacyjną przeprowadzono trzydzieści trzy razy - oddzielnie dla każdego czynnika i każdego roku. W osiemnastu przypadkach hipotezę $H_{0}$ o niezależności tego, czy respondent uznaje dany czynnik za ważny, od tego, jakie jest jego wykształcenie, należało odrzucić

11 Przy podejmowaniu decyzji w teście niezależności chi-kwadrat bierze się pod uwagę jednostronny (a konkretnie - prawostronny) obszar krytyczny, który określa nierówność $\chi^{2} \geq \chi_{\alpha}^{2}$. Statystyka $\quad \chi_{\alpha}^{2}$ jest wartością krytyczną odczytaną z tablic rozkładu chi-kwadrat dla przyjętego z góry poziomu istotności $\alpha$ i dla $(r-1)(s-1)$ stopni swobody, gdzie $r$ oznacza liczbę wariantów pierwszej cechy, a $s$ liczbę wariantów drugiej cechy. Obliczoną wartość statystyki testowej $\chi^{2}$ porównuje się z wartością krytyczną $\chi_{\alpha}^{2}$ i jeśli spełniona jest nierówność $\chi^{2} \geq \chi_{\alpha}^{2}$, to przy przyjętym poziomie istotności hipotezę zerową należy odrzucić na korzyść hipotezy alternatywnej. Orzeka się wówczas, że rozpatrywane cechy są zależne. Gdy natomiast zachodzi nierówność $\chi^{2}<\chi_{\alpha}^{2}$, nie ma podstaw do odrzucenia hipotezy zerowej o niezależności badanych cech. Por. P. Sulewski, Modyfikacja testu niezależności, „Wiadomości Statystyczne” 2013, nr 10 (629), s. 2-3.

12 Do obliczenia współczynnika $V$ Cramera służy wzór:

$$
V=\sqrt{\frac{\chi^{2}}{n \min (r-1, s-1)}},
$$

gdzie $n$ jest liczbą przebadanych jednostek statystycznych. Zob. B. Pułaska-Turyna, Statystyka dla ekonomistów, Difin, Warszawa 2005, s. 254.

13 A.D. Aczel, Statystyka w zarządzaniu, Wydawnictwo Naukowe PWN, Warszawa 2000, s. 758 . 
na rzecz hipotezy alternatywnej, orzekając jednocześnie, że rozpatrywane cechy są zależne. Uzyskane odchylenia między liczebnościami empirycznymi i teoretycznymi były wystarczająco duże, aby odrzucić przypuszczenie o niezależności. Z kolei w przypadku piętnastu przeprowadzonych weryfikacji nie było podstaw do odrzucenia hipotezy $H_{0}$ o niezależności badanych cech. Oznacza to, że częstość względna uznawania danego czynnika za ważny nie zależała od wykształcenia respondenta.

W następnym etapie dla każdego roku i czynnika objętego analizą określono stosunek liczebności empirycznych $n_{i j}$ i odpowiadających im liczebności teoretycznych $\hat{n}_{i j}$. Wyznaczono także udział procentowy składników obliczonej statystyki $\chi^{214}$. Wspomniane informacje umieszczono w tabeli 1.

Analiza informacji zawartych $w$ tabeli 1 pozwala na wyciągnięcie wniosku, że osoby z wyższym i policealnym wykształceniem cenią sobie pracę zgodną z umiejętnościami, dużą samodzielność, możliwość rozwoju osobistego oraz możliwość szybkiego awansowania dużo bardziej niż osoby z pozostałymi poziomami wykształcenia. Natomiast respondenci ze średnim wykształceniem przywiązują relatywnie większą wagę do braku napięć i stresów oraz do stabilności zatrudnienia niż osoby lepiej albo gorzej od nich wykształcone. Z kolei ci, którzy mają wykształcenie zasadnicze zawodowe, gimnazjalne, podstawowe i niższe, cenią odpowiednią płacę oraz dogodne godziny pracy stosunkowo wyżej niż osoby z co najmniej średnim wykształceniem. Szczegółowe wnioski z przeprowadzonych badań umieszczono w tabeli 2 .

14 Statystykę $\chi^{2}$, którą przyjmuje się jako syntetyczną miarę odchyleń liczebności rzeczywistych od liczebności teoretycznych, oblicza się zgodnie z formułą:

$$
\chi^{2}=\sum_{i=1}^{r} \sum_{j=1}^{s} \frac{\left(n_{i j}-\hat{n}_{i j}\right)^{2}}{\hat{n}_{i j}} \quad(i=1,2, \ldots, r ; j=1,2, \ldots, s) .
$$

Por. H. Ankarali, S. Cangur, Comparison of Pearson Chi-square and Log-likelihood Ratio Statistics in $R \times C$ Tables With Regard to Type I Error, „International Journal of Basic and Clinical Studies (IJBCS)" 2013, No. 2 (2), s. 95. 
Tabela 1. Zależności między wykształceniem respondenta i czynnikami określającymi atrakcyjność pracy

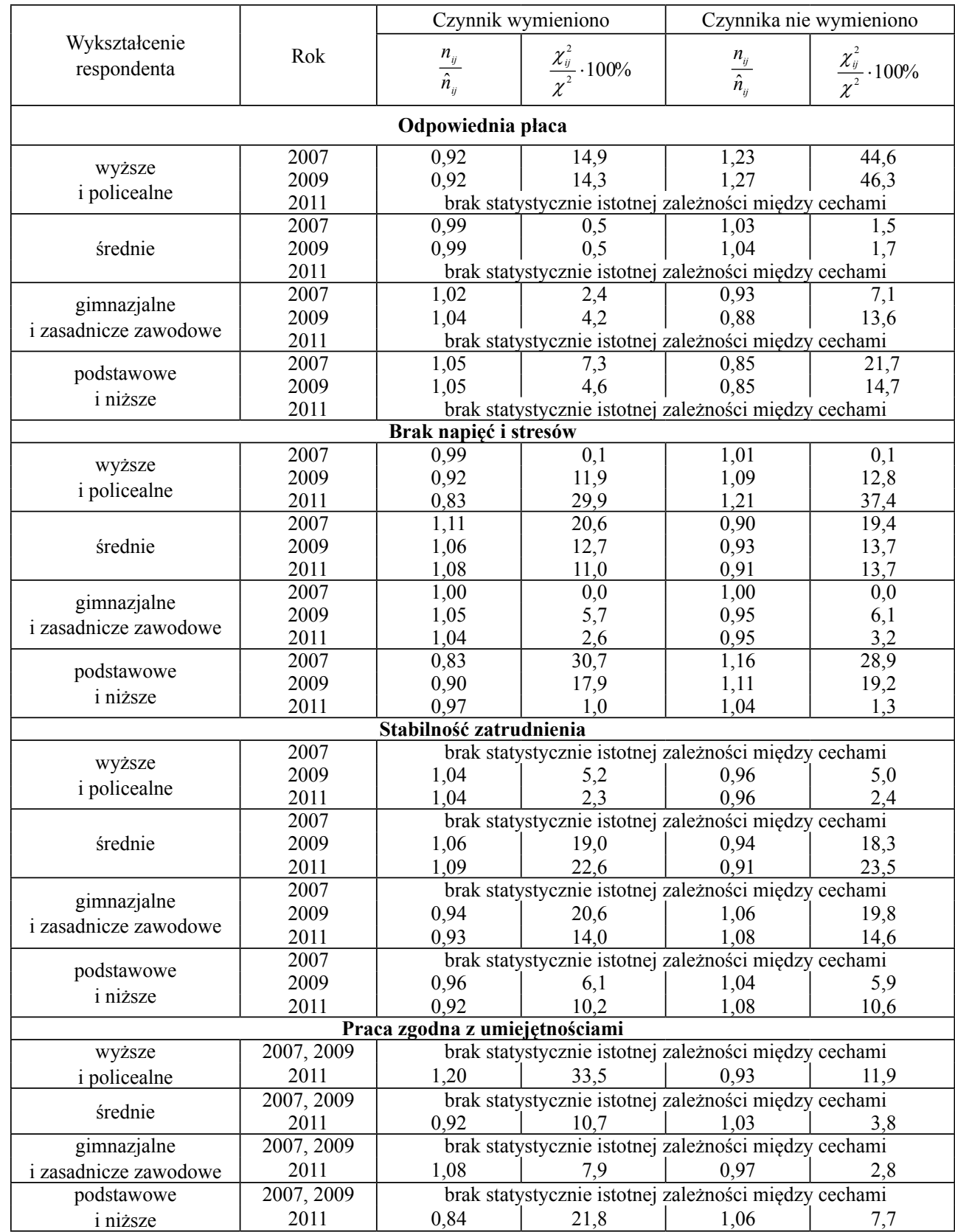




\begin{tabular}{|c|c|c|c|c|c|}
\hline \multicolumn{6}{|c|}{ Duża samodzielność } \\
\hline & 2007 & 1,36 & 31,0 & 0,92 & 6,7 \\
\hline wyzsze & 2009 & 1,42 & 36,2 & 0,89 & 9,5 \\
\hline & 2011 & 1,28 & 37,5 & 0,92 & 10,9 \\
\hline \multirow{3}{*}{ średnie } & 2007 & 1,12 & 7,0 & 0,97 & 1,5 \\
\hline & 2009 & 1,10 & 4,0 & 0,97 & 1,0 \\
\hline & 2011 & 1,07 & 4,4 & 0,98 & 1,3 \\
\hline \multirow{3}{*}{$\begin{array}{c}\text { gimnazjalne } \\
\text { i zasadnicze zawodowe }\end{array}$} & 2007 & 0,90 & 3,5 & 1,02 & 0,7 \\
\hline & 2009 & 0,88 & 4,4 & 1,03 & 1,2 \\
\hline & 2011 & 0,89 & 8,1 & 1,03 & 2,4 \\
\hline \multirow{3}{*}{$\begin{array}{l}\text { podstawowe } \\
\text { i niższe }\end{array}$} & 2007 & 0,62 & 40,8 & 1,08 & 8,8 \\
\hline & 2009 & 0,61 & 34,7 & 1,10 & 9,1 \\
\hline & 2011 & 0,77 & 27,4 & 1,07 & 8,0 \\
\hline \multicolumn{6}{|c|}{ Możliwość rozwoju osobistego } \\
\hline \multirow{3}{*}{$\begin{array}{c}\text { wyższe } \\
\text { i policealne }\end{array}$} & 2007 & 1,87 & 42,3 & 0,76 & 11,6 \\
\hline & 2009 & 1,81 & 42,2 & 0,73 & 13,9 \\
\hline & 2011 & 2,15 & 54,2 & 0,72 & 13,2 \\
\hline \multirow{3}{*}{ średnie } & 2007 & 1,19 & 3,8 & 0,95 & 1,0 \\
\hline & 2009 & 1,14 & 2,2 & 0,95 & 0,7 \\
\hline & 2011 & 1,07 & 0,4 & 0,98 & 0,1 \\
\hline \multirow{3}{*}{$\begin{array}{c}\text { gimnazjalne } \\
\text { i zasadnicze zawodowe }\end{array}$} & 2007 & 0,64 & 11,4 & 1,10 & 3,1 \\
\hline & 2009 & 0,71 & 8,5 & 1,10 & 2,8 \\
\hline & 2011 & 0,57 & 12,1 & 1,11 & 3,0 \\
\hline \multirow{3}{*}{$\begin{array}{l}\text { podstawowe } \\
\text { i niższe }\end{array}$} & 2007 & 0,43 & 21,0 & 1,16 & 5,8 \\
\hline & 2009 & 0,43 & 22,4 & 1,19 & 7,3 \\
\hline & 2011 & 0,44 & 13,7 & 1,14 & 3,3 \\
\hline \multicolumn{6}{|c|}{ Dogodne godziny pracy } \\
\hline \multirow{3}{*}{$\begin{array}{l}\text { wyższe } \\
\text { i policealne }\end{array}$} & 2007 & 0,69 & 38,4 & 1,07 & 8,5 \\
\hline & 2009 & 0,76 & 52,2 & 1,05 & 11,8 \\
\hline & 2011 & 0,79 & 42,9 & 1,04 & 8,8 \\
\hline \multirow{3}{*}{ średnie } & 2007 & 0,91 & 6,2 & 1,02 & 1,4 \\
\hline & 2009 & 0,99 & 0,1 & 1,00 & 0,0 \\
\hline & 2011 & 0,95 & 4,2 & 1,01 & 0,9 \\
\hline \multirow{3}{*}{$\begin{array}{l}\text { gimnazjalne } \\
\text { i zasadnicze zawodowe }\end{array}$} & 2007 & 1,22 & 31,3 & 0,95 & 6,9 \\
\hline & 2009 & 1,14 & 28,3 & 0,97 & 6,4 \\
\hline & 2011 & 1,09 & 11,0 & 0,98 & 2,3 \\
\hline \multirow{3}{*}{$\begin{array}{l}\text { podstawowe } \\
\text { i niższe }\end{array}$} & 2007 & 1,11 & 5,9 & 0,97 & 1,3 \\
\hline & 2009 & 1,03 & 0,9 & 0,99 & 0,2 \\
\hline & 2011 & 1,16 & 25,0 & 0,97 & 5,1 \\
\hline \multicolumn{6}{|c|}{ Możliwość szybkiego awansowania } \\
\hline \multicolumn{6}{|c|}{\begin{tabular}{l|l}
\multicolumn{2}{c}{ Mozliwosc szybkiego awansowanıa } \\
2007,2009 & brak statystycznie istotnej zależności między cechami
\end{tabular}} \\
\hline i policealne & 2011 & 1,59 & 45,7 & 0,98 & 1,5 \\
\hline \multirow{2}{*}{ średnie } & 2007,2009 & \multicolumn{4}{|c|}{ brak statystycznie istotnej zależności między cechami } \\
\hline & 2011 & 1,18 & 7,7 & 0,99 & 0,3 \\
\hline gimnazjalne & 2007,2009 & \multicolumn{4}{|c|}{ brak statystycznie istotnej zależności między cechami } \\
\hline i zasadnicze zawodowe & 2011 & 0,70 & 18,1 & 1,01 & 0,6 \\
\hline podstawowe & 2007,2009 & \multicolumn{4}{|c|}{ brak statystycznie istotnej zależności między cechami } \\
\hline i niższe & 2011 & 0,57 & 25,4 & 1,01 & 0,8 \\
\hline \multicolumn{6}{|c|}{ Zajęcie poważane przez ludzi, długi urlop, możliwość wykonywania pracy w domu } \\
\hline $2007,2009,2$ & & brak & znie is & ości n & $\mathrm{ami}$ \\
\hline
\end{tabular}

Źródło: obliczenia własne na podstawie: Kapitał ludzki w Polsce w 2010 r. (2012 r.), GUS, Gdańsk 2012, s. 344; Kapitał ludzki w Polsce w 2012 r., GUS, Gdańsk 2014, s. 254; Mały rocznik statystyczny Polski 2009 (2011, 2013), GUS, Warszawa 2009, s. 118; Mały rocznik statystyczny Polski 2011, GUS, Warszawa 2011, s. 121; Mały rocznik statystyczny Polski 2013, GUS, Warszawa 2013, s. 124. 
Tabela 2. Czynniki pracy szczególnie istotne oraz mające relatywnie najmniejsze znaczenie w zależności od wykształcenia pracownika

\begin{tabular}{|l|l|l|}
\hline \multicolumn{1}{|c|}{$\begin{array}{c}\text { Czynnik określający } \\
\text { atrakcyjność pracy zawodowej }\end{array}$} & $\begin{array}{c}\text { Czynnik jest najczęściej } \\
\text { wymieniany przez osoby } \\
\text { posiadające wykształcenie: }\end{array}$ & $\begin{array}{c}\text { Czynnik jest najrzadziej } \\
\text { wymieniany przez osoby } \\
\text { posiadające wykształcenie: }\end{array}$ \\
\hline Odpowiednia płaca & podstawowe i niższe & wyższe i policealne \\
\hline Brak napięć i stresów & średnie & $\begin{array}{l}\text { wyższe i policealne } \\
\text { oraz podstawowe i niższe }\end{array}$ \\
\hline Stabilność zatrudnienia & średnie & $\begin{array}{l}\text { zasadnicze zawodowe } \\
\text { i niższe }\end{array}$ \\
\hline Praca zgodna z umiejętnościami & wyższe i policealne & podstawowe i niższe \\
\hline Duża samodzielność & wyższe i policealne & podstawowe i niższe \\
\hline Możliwość rozwoju osobistego & wyższe i policealne & $\begin{array}{l}\text { zasadnicze zawodowe } \\
\text { i niższe }\end{array}$ \\
\hline Dogodne godziny pracy & $\begin{array}{l}\text { zasadnicze zawodowe } \\
\text { i niższe }\end{array}$ & wyższe i policealne \\
\hline Możliwość szybkiego awansowania & wyższe i policealne & $\begin{array}{l}\text { zasadnicze zawodowe } \\
\text { i niższe }\end{array}$ \\
\hline $\begin{array}{l}\text { Zajęcie poważane przez ludzi, } \\
\text { długi urlop, możliwość wykonywania } \\
\text { pracy w domu }\end{array}$ & $\begin{array}{l}\text { brak statystycznie istotnej zależności między danym czynni- } \\
\text { kiem a wykształceniem respondenta }\end{array}$ \\
\hline
\end{tabular}

Źródło: opracowanie własne na podstawie tabeli 1.

W wyniku przeprowadzenia testów istotności stwierdzono, że wykształcenie w statystycznie istotny sposób wpływa na zróżnicowanie Polaków pod względem tego, jaką wagę przypisują charakterystykom określającym atrakcyjność pracy. Dysponując taką informacją, warto dodatkowo sprawdzić, w przypadku których z jedenastu rozpatrywanych czynników poziom wykształcenia ma największy wpływ na odpowiedzi respondentów, a w przypadku których wpływ wykształcenia jest najmniejszy. W tym celu dla każdego czynnika oraz dla każdego roku obliczono wartość statystyki $V$ Cramera. Statystyka ta jest wielkością niemianowaną i unormowaną - przyjmuje wartości wyłącznie z przedziału $\langle 0,1\rangle$. Jeżeli jest równa 0 , to między cechami nie występuje zależność. Z kolei im bliższa jest liczby 1 , tym zależność jest silniejsza.

W tabeli 3 zaprezentowano wartości współczynnika $V$ Cramera otrzymane dla poszczególnych lat i jedenastu rozpatrywanych czynników. Najjaśniejszym kolorem szarym wyróżniono te pola, dla których współczynnik $V$ Cramera był większy od liczby 0,08 , ale mniejszy niż 0,1 , ciemniejszym kolorem szarym zaznaczono te 
miejsca, w przypadku których otrzymano $0,1 \leq V<0,2$, natomiast najciemniejszym kolorem szarym pokryto te pola, dla których $V \geq 0,2$.

Tabela 3. Wartości statystyki $V$ Cramera

\begin{tabular}{|c|c|c|c|}
\hline \multirow{2}{*}{$\begin{array}{l}\text { Czynnik wymieniany przez respondenta } \\
\text { jako ważny w pracy zawodowej }\end{array}$} & \multicolumn{3}{|c|}{ Wartości statystyki V } \\
\hline & $2007 \mathrm{r}$. & 2009 r. & $2011 \mathrm{r}$. \\
\hline Możliwość rozwoju osobistego & 0,261 & 0,266 & 0,295 \\
\hline Duża samodzielność & 0,115 & 0,134 & 0,094 \\
\hline Brak napięć i stresów & 0,099 & 0,075 & 0,099 \\
\hline Odpowiednia płaca & 0,073 & 0,083 & $(*)$ \\
\hline Dogodne godziny pracy & 0,090 & 0,060 & 0,057 \\
\hline Stabilność zatrudnienia & $(*)$ & 0,053 & 0,076 \\
\hline Praca zgodna z umiejętnościami & $(*)$ & $(*)$ & 0,075 \\
\hline Możliwość szybkiego awansowania & $(*)$ & $(*)$ & 0,066 \\
\hline Zajęcie poważane przez ludzi & $(*)$ & $(*)$ & $(*)$ \\
\hline Możliwość wykonywania pracy w domu & $(*)$ & $(*)$ & $(*)$ \\
\hline Długi urlop & $(*)$ & $(*)$ & $(*)$ \\
\hline
\end{tabular}

(*) brak statystycznie istotnej zależności między cechami.

Źródło: obliczenia własne na podstawie: Kapitał ludzki w Polsce w 2010 r. (2012 r.), GUS, Gdańsk 2012, s. 344; Kapitat ludzki w Polsce w 2012 r., GUS, Gdańsk 2014, s. 254; Mały rocznik statystyczny

Polski 2009, GUS, Warszawa 2009, s. 118; Mały rocznik statystyczny Polski 2011, GUS, Warszawa 2011, s. 121; Mały rocznik statystyczny Polski 2013, GUS, Warszawa 2013, s. 124.

Obliczone wartości statystyki $V$ pozwalają stwierdzić, że poziom wykształcenia pracownika ma największy wpływ na znaczenie, jakie przypisuje on możliwościom rozwoju osobistego. Na kolejnych miejscach znalazły się duża samodzielność i brak napięć i stresów. Z kolei w przypadku możliwości wykonywania pracy w domu, zajęcia poważanego przez ludzi oraz długiego urlopu wpływ wykształcenia na względną częstość wymieniania czynnika jako ważnego jest statystycznie nieistotny.

\section{Podsumowanie}

Wartość wynagrodzenia jest najważniejszym kryterium przy ocenie jakości życia zawodowego w przypadku wszystkich Polaków bez względu na wykształcenie. 
Okazuje się jednak, że istnieje szereg innych czynników określających atrakcyjność danej pracy. Co ciekawe, ranga przypisywana poszczególnym czynnikom jest inna w przypadku osób z wyższym wykształceniem, inna w przypadku osób ze średnim wykształceniem oraz inna w przypadku osób z wykształceniem zasadniczym zawodowym i niższym. Jedenaście czynników wziętych pod uwagę w niniejszym badaniu można więc scharakteryzować pod względem ich ważności dla respondentów oraz wpływu wykształcenia badanych na to, czy wymieniają dany element jako istotny. Na rysunku $2^{15}$ zaprezentowano miejsce poszczególnych czynników w dwuwymiarowym układzie współrzędnych, gdzie wartość odciętej obrazuje siłę oddziaływania wykształcenia na zmienność danego czynnika, a wartość rzędnej pokazuje ogólny odsetek osób uznających dany czynnik za ważny.

Rysunek 2. Istotność czynnika określającego atrakcyjność pracy oraz wrażliwość czynnika na poziom wykształcenia

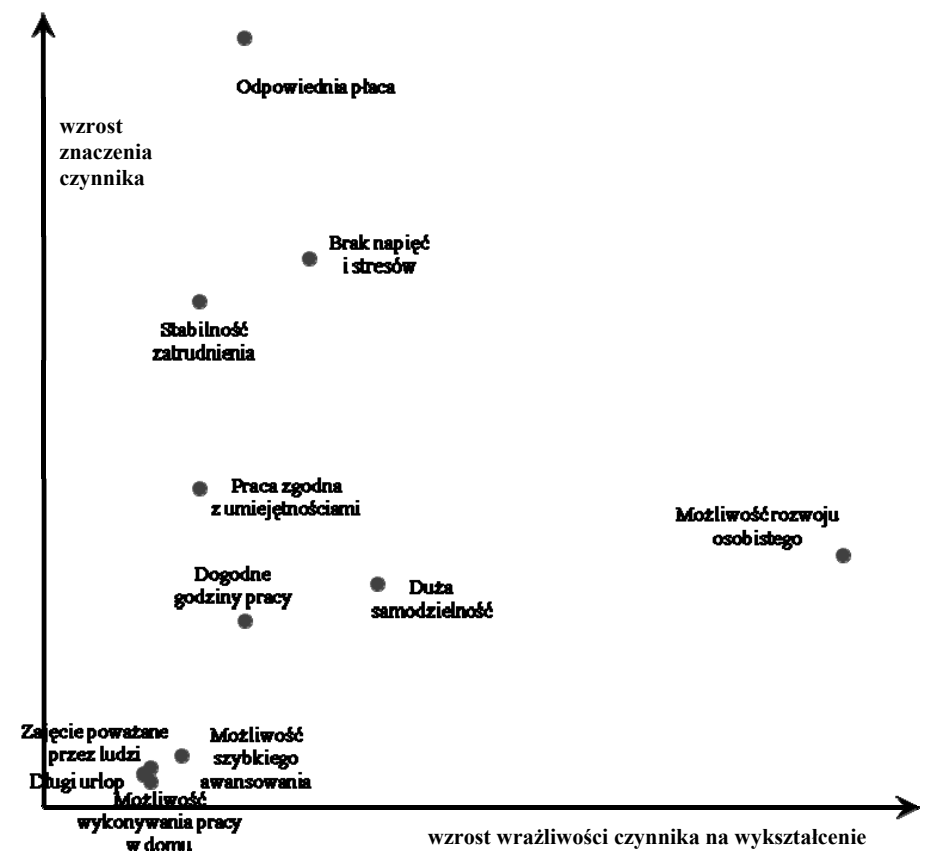

Źródło: opracowanie własne na podstawie rysunku 1 i tabeli 3. 2009 i 2011.

15 Na rysunku przedstawiono wyniki analizy przeprowadzonej w oparciu o średnie z lat 2007, 
Reasumując, najważniejszymi czynnikami określającymi atrakcyjność pracy są odpowiednia płaca, brak napięć i stresów oraz stabilność zatrudnienia, a najbardziej wrażliwe na poziom wykształcenia są czynniki: możliwość rozwoju osobistego, duża samodzielność oraz brak napięć i stresów.

Należy z całą mocą podkreślić, że właściwie dobrane motywatory to te, które są efektywne oraz pozwalają na osiągnięcie zamierzonego celu. Dla skutecznego kierowania personelem sprawą kluczową jest zatem poznanie indywidualnej struktury potrzeb każdego podwładnego. Bodźce motywacyjne stosowane wobec poszczególnych osób nie mogą być przypadkowe, a winny być odpowiednio dobrane, tak aby ostatecznie okazały się zgodne $\mathrm{z}$ oczekiwaniami pracowników ${ }^{16}$. Trzeba przy tym pamiętać, że na hierarchię potrzeb danej osoby znaczny wpływ ma jej wykształcenie, co wykazano w niniejszym artykule. Oznacza to, że w zarządzaniu powinno brać się pod uwagę zróżnicowanie ludzi w zakresie ich aspiracji i źródeł satysfakcji zawodowej, które to zróżnicowanie wynika m.in. z odmiennego wykształcenia uzyskanego przez poszczególne osoby. Dzięki przedstawionym w artykule badaniom wiadomo już, że choć ranga przypisywana różnym bodźcom motywacyjnym w przypadku każdej osoby jest inna, to jednak w różnorodności tej można znaleźć pewne prawidłowości.

Wyniki przeprowadzonej analizy mają bardzo duży walor praktyczny i mogą posłużyć przełożonym jako użyteczny zbiór podpowiedzi dotyczących sposobów motywowania podwładnych. Autorki ufają, że dzięki poznaniu istniejących prawidłowości łatwiejsze stanie się zrozumienie przez pracodawców dążeń i pragnień pracowników.

Zaprezentowane badania stały się przyczynkiem do dalszych dociekań autorek. Niewątpliwie bowiem nie tylko wykształcenie różnicuje pracowników pod względem preferencji w obszarze otrzymywanych bodźców motywacyjnych, ale również szereg innych cech, a w tym zapewne cech demograficznych. Dlatego w kolejnych opracowaniach sprawdzono, w jakim stopniu zmienne, takie jak wiek, płeć i miejsce zamieszkania respondenta, rzutują na to, które czynniki są dla niego najważniejsze w określaniu atrakcyjności pracy zawodowej.

16 K. Podolski, W. Turnowiecki, Polityka społeczna, Wydawnictwo Uniwersytetu Gdańskiego, Gdańsk 2001, s. 85. 


\section{Literatura}

Aczel A.D., Statystyka w zarzadzaniu, Wydawnictwo Naukowe PWN, Warszawa 2000.

Ankarali H., Cangur S., Comparison of Pearson Chi-square and Log-likelihood Ratio Statistics in $R \times C$ Tables With Regard to Type I Error, „International Journal of Basic and Clinical Studies (IJBCS)" 2013, No. 2 (2).

Drzeżdżon W., Przeobrażenia polskiego rynku pracy u progu XXI wieku. Wyzwania dla pedagogiki pracy, „Studia Gdańskie. Wizje i Rzeczywistość” 2011, t. 8.

Drzeżdżon W., Wartości pracy wśród młodzieży szkół zawodowych, Bernardinum, Tczew 2006

Gitling M., Człowiek i jego praca, „Nierówności Społeczne a Wzrost Gospodarczy” 2013, nr 33 .

Głowacka M., Głowacka-Rębała A., Nowakowska I., Rasińska R., Zarządzanie jakościa pracy członków organizacji, „Problemy Zarządzania” 2011, Vol. 9, nr 4 (34).

Kapitat ludzki w Polsce w 2010 r., GUS, Gdańsk 2012.

Kapitat ludzki w Polsce w 2012 r., GUS, Gdańsk 2014.

Kozioł L., Motywacja w pracy. Determinanty ekonomiczno-organizacyjne, Wydawnictwo Naukowe PWN, Warszawa-Kraków 2002.

Kunasz M., Zasoby przedsiębiorstwa w ujęciu teorii ekonomii, „Gospodarka Narodowa” 2006, nr 10.

Maty rocznik statystyczny Polski 2009, GUS, Warszawa 2009.

Maty rocznik statystyczny Polski 2011, GUS, Warszawa 2011.

Maty rocznik statystyczny Polski 2013, GUS, Warszawa 2013.

Mazur-Wierzbicka E., Kompetencje pokolenia $Y$ - wybrane aspekty, „Studia i Prace Wydziału Nauk Ekonomicznych i Zarządzania” 2015, t. 3, nr 39.

Podolski K., Turnowiecki W., Polityka społeczna, Wydawnictwo Uniwersytetu Gdańskiego, Gdańsk 2001.

Polek-Duraj K., Humanizacja pracy w aspekcie jakości pracy i życia spoleczeństwa, „Studia i Materiały Miscellanea Oeconomicae" 2010, $\mathrm{nr} 2$.

Pułaska-Turyna B., Statystyka dla ekonomistów, Difin, Warszawa 2005.

Sulewski P., Modyfikacja testu niezależności, „Wiadomości Statystyczne” 2013, nr 10 (629).

Wyrostek M., Praca jako determinanta jakości życia czlowieka, Prace i Materiały Wydziału Zarządzania Uniwersytetu Gdańskiego 2013, „Zarządzanie i Finanse”, nr 1, cz. 3.

Zalewska A., Wiek, płeć i stanowisko pracy a zadowolenie z pracy, „Psychologia Jakości Życia" 2009, t. 8, nr 1 . 


\title{
FACTORS DETERMINING QUALITY OF PROFESSIONAL LIFE WITH RESPECT TO EDUCATIONAL LEVEL OF EMPLOYEE
}

\begin{abstract}
The factor that is most often mentioned as crucial for assessing the quality of professional live is the appropriate wage. Other characteristics of work that describe its attractiveness are no tensions and stress, stability of employment and job matching the skills. The purpose of the article is to answer the question how the educational level of people influences the fact that some factors are considered by them to be the most important at work and some have - according to their opinion-minor importance. The research has proven that education has the greatest impact on the answer given by a person when is asked if personal development is the vital factor at work.
\end{abstract}

Translated by Anna Turczak

Keywords: quality of professional life, educational level

JEL Codes: J28, M54 